\title{
RING OF LIFE : SEBUAH STRATEGI PENYELAMATAN TERUMBU KARANG
}

\author{
Fransisca Angeline Joham ${ }^{1)}$, Denny Husin ${ }^{2)}$ \\ 1)Program Studi S1 Arsitektur, Fakultas Teknik, Universitas Tarumanagara, fransisca.angeline27@gmail.com \\ 2) Program Studi S1 Arsitektur, Fakultas Teknik, Universitas Tarumanagara, denny@ft.untar.ac.id \\ Masuk:04-07-2021, revisi: 14-08-2021, diterima untuk diterbitkan: 23-10-2021
}

\begin{abstract}
Abstrak
Pulau Samalona di Makassar merupakan salah satu destinasi wisata yang terkenal dan merupakan rumah bagi penghuninya yang sebagian besar berprofesi sebagai nelayan. Pulau Samalona mengalami fenomena abrasi yang menyebabkan bentuk dan luasaannya berubahubah dari tahun ke tahun sehingga pulau ini diisukan akan tenggelam. Penyebab terjadinya abrasi pada Pulau Samalona adalah masalah rusaknya tutupan karang di sekitar pulau yang merupakan penahan ombak alami. Rusaknya terumbu karang disebabkan oleh ulah manusia yang tidak bertanggung jawab, seperti menangkap ikan menggunakan bom dan bahan kimia berbahaya, reklamasi yang menyebabkan air laut tercemar,dan meningkatnya suhu bumi. Oleh sebab itu, perlu dibangun pusat penelitian dan restorasi terumbu karang di Pulau Samalona. Ring of Life bertujuan untuk untuk meningkatkan kualitas tutupan karang menjadi status baik, mengidentifikasi sumber pencemaran air, menarik minat wisatawan untuk lebih peduli dengan kondisi terumbu karang, dan mencegah tenggelamnya Pulau Samalona. Proyek ini menggunakan metode simbiosis hibrid yang menyatukan dua elemen berbeda yaitu manusia dan laut, restorasi rekayasa evolusi, dan penelitian air. Proyek ini terdiri dari program penelitian, restorasi, wisata, pengelola, dan servis yang dituangkan dalam gaya bangunan futuristik.
\end{abstract}

Kata kunci: arsitektur; laut; penelitian; restorasi; ring of life; terumbu karang.

\begin{abstract}
Samalona Island in Makassar is one of the famous tourist destinations and is home to its residents, most of whom work as fishermen. Samalona Island experienced an abrasion phenomenon which causes its shape and area to change from year to year so that the island is rumored to be sinking. The cause of abrasion on Samalona Island is the damage to the coral cover around the island which is a natural wave barrier. Damage to coral reefs is caused by irresponsible human activities, such as fishing using bombs and dangerous chemicals, reclamation that causes sea water to be polluted, and earth's temperature rise. Therefore, it is necessary to build a coral reef research and restoration center on Samalona Island. Ring of Life aims to improve the quality of coral cover to good status, identify sources of water pollution, attract tourists to be more concerned with the condition of coral reefs, and prevent the sinking of Samalona Island. This project uses a hybrid symbiosis method that brings together two different elements, namely humans and the sea, evolutionary engineering restoration, and water research. This project consists of research, restoration, tourism, management, and service programs that are outlined in a futuristic building style.
\end{abstract}

Keywords: architecture; coral reefs; research; restoration; ring of life; sea.

\section{PENDAHULUAN}

\section{Latar Belakang}

Pulau Samalona merupakan salah satu pulau yang menjadi tempat wisata favorit di Makassar, Sulawesi Selatan. Sangat disayangkan bentuk pulau ini terus berubah-ubah dikarenakan abrasi air laut. Menurut beberapa orang kelautan, Pulau Samalona kemungkinan akan habis ditelan air laut di masa yang akan datang. (Arsy Tours, 2020). Salah satu penyebab terjadinya fenomena 
tersebut adalah rusaknya terumbu karang di Kepulauan Spermonde, Makassar, Sulawesi Selatan. Kepulauan Spermonde merupakan salah satu sumber penghidupan bagi nelayan, juga masyarakat Makassar secara keseluruhan, mulai dari sektor perikanan hingga wisata. (Anantara, 2019)

Kondisi tutupan karang di Kepulauan Spermonde dalam ancaman besar. Menurut data dari Marine Science Diving Club (MSDC) Universitas Hasanuddin, tutupan karang hidup Pulau Barrang Lompo tercatat 40\% (kategori sedang), Pulau Barrang Caddi sebesar 38\% (kategori sedang), dan Pulau Samalona sebesar 30\% (kategori buruk). Penyebab kerusakan yang pertama adalah penangkapan ikan menggunakan bahan kimia, yaitu bom, bius dan lainnya (Kumparan Travel, 2019). Dilihat dari ciri-ciri kerusakan sebagian besar diakibatkan oleh dampak reklamasi proyek Centre Point of Indonesia. (Chandra, 2016). Total nilai manfaat ekonomi ekosistem terumbu karang di perairan Spermonde berdasarkan beberapa penelitian berkisar dari Rp30,3 miliar lebih hingga Rp1,6 triliun lebih per hektare per tahun. Bila ekosistem Spermonde rusak parah, kerugian bukan hanya akan dialami oleh nelayan atau pelaku usaha perikanan. Pemerintah daerah juga dapat kehilangan potensi pemasukan dari sektor pariwisata. (Anantara, 2019).

Tutupan karang di Pulau Samalona sebesar 30\% yang masuk dalam kategori buruk jika dibandingkan dengan pulau di sekitarnya. Oleh karena itu, perlu segera dilaksanakan restorasi terumbu karang di perairan Pulau Samalona.

\section{Rumusan Permasalahan}

Tutupan karang di sekitar Pulau Samalona hanya tersisa sebesar 30\% yang masuk dalam kategori buruk sehingga perlu direstorasi. Kerusakan karang menyebabkan hilangnya penahan ombak alami bagi Pulau Samalona sehingga terjadi abrasi dan terancam tenggelam. Arsitektur beyond ecology perlu mengambil peran dalam mengembalikan kondisi tutupan terumbu karang.

\section{Tujuan}

Mengembalikan status tutupan karang menejadi baik, mencegah tenggelamnya pulau samalona, dan menerapkan arsitektur beyond ecology dalam mengembalikan kondisi tutupan terumbu karang.

\section{KAJIAN LITERATUR}

\section{Pusat Penelitian dan Restorasi}

Pusat adalah bangunan di mana orang memiliki pertemuan, mengambil bagian dalam kegiatan tertentu, atau mendapatkan bantuan dari beberapa jenis. Penelitian pekerjaan yang melibatkan mempelajari sesuatu dan mencoba untuk menemukan fakta-fakta tentang hal itu. (Collins, n.d.). Restorasi adalah tindakan untuk membawa ekosistem yang telah terdegradasi kembali, semirip mungkin, dengan kondisi aslinya. (Edwards \& Gomez, 2007)

\section{Terumbu Karang}

Terumbu karang merupakan struktur yang berada di dasar laut berupa deposit kalsium karbonat di laut yang dihasilkan oleh hewan karang. Karang adalah hewan yang tidak bertulang belakang yang termasuk dalam Filum Coelenterata (hewan berrongga) atau Cnidaria. (Zurba, 2019) Terumbu karang sebagian besar ditemui pada perairan tropis, pada umumnya karang hidup di pinggir pantai atau daerah yang terkena cahaya matahari kurang lebih $50 \mathrm{~m}$ di bawah permukaan laut. (Lubis, et al., 2016). Berikut merupakan penentuan kategori kondisi terumbu karang berdasarkan persentase tutupan karang hidup. 
Tabel 1. Kategori Kondisi Terumbu Karang Berdasarkan Tutupan Karang Hidup

\begin{tabular}{ccc} 
No & Presentase Tutupan Karang Hidup $(H C)$ & Kategori \\
1 & $H C \leq 25 \%$ & Jelek / poor \\
2 & $25 \%<H C \leq 50 \%$ & Cukup / fair \\
3 & $50 \%<H C \leq 75 \%$ & Baik / good \\
4 & $H C>75 \%$ & Sangat baik / excellent \\
\hline
\end{tabular}

Sumber: hidup (Hadi, et al., 2018)

\section{Parameter Beyond Ecology:}

Parameter dalam arsitektur menuju beyond ecology (Sutanto, 2021):

a. Energy and emission: Kemampuan untuk menerapkan zero $\mathrm{CO} 2$ emission dalam pengoperasionalan bangunan dan meminimalisis efek karbon dalam material dan konstruksi.

b. Adaptation: Kemampuan untuk melakukan riset dan desain yang berkaitan dengan berbagai dampak seperti naiknya suhu bumi, naiknya permukaan laut, kekeringan, banjir, kelangkaan pangan, dan perubahan populasi.

c. Resilience: Kemampuan untuk membangun hunian dan pemulihan cepat setelah kejadian guncangan bencana alam, gangguan listrik atau iklim.

d. Sustainable digital: Kemampuan untuk melihat data-data lingkungan sebagai big data dalam menentukan taktik dan strategi dalam membangun kualitas spasial.

e. New technology: Kemampuan memanfaatkan teknologi terbaru untuk meningkatkan kualitas dan terapan ruang - konstruksi dan program bangunan.

f. Context: Kemampuan dalam melihat posisi tempat dalam hubungan dengan lingkungan (flora - fauna - abiotik) pada sebuah konfigurasi keruangan akan ditempatkan.

\section{METODE}

\section{Metode Desain}

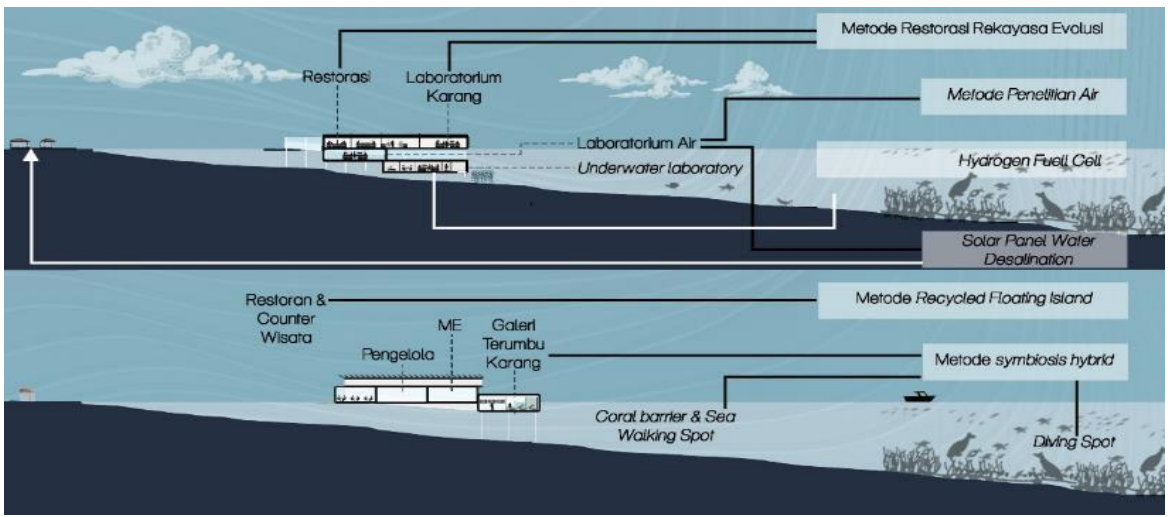

Gambar 1. Diagram Metode Perancangan

Sumber: Joham, 2021

Proyek ini didesain menggunakan metode simbiosis hibrida yang menggabungkan dua elemen berbeda yaitu manusia dan laut untuk hidup bersama. Simbisosis hibrida sebagai sebuah konsep sekaligus metode desain harus dilihat dalam arti yang lebih luas, dengan terminology dasarnya adalah living together, maka dapat dikatakan bahwa ada beberapa konsep yang dapat didekatkan dengan pengertian simbiosis dan arsitektur, yaitu parasit, infill, dan hybrid. Hybrid adalah sebuah campuran, sesuatu yang dibuat dengan menggabungkan dua elemen yang berbeda; sebuah campuran adalah kombinasi yang sesuai dari penggunaan ganda, di dalam struktur tunggal atau tempat dalam lingkungan. ( Sutanto, 2020)

Menggunakan metode rekayasa evolusi adalah cara untuk merestorasi karang, penelitian kualitas air, solar panel water desalination, hydrogen fuell cell, dan recycled floating island. 


\section{DISKUSI DAN HASIL}

\section{Program}

Program terdiri dari penelitian dan restorasi sebesar $60 \%$, wisata sebesar $25 \%$, pengelola sebesar $5 \%$, dan servis sebesar $10 \%$.

Program Penelitian dan Restorasi (60\%)

1. Laboratorium Pengamatan

Memantau kesehatan dan keanekaragaman terumbu karang.

2. Laboratorium Karang

Mengembangkan karang yang dapat bertahan dalam kondisi lingkungan yang buruk, dengan cara:

- Karang dipotong lalu diletakkan di dalam akuarium percobaan (coral nurseries).

- Dipaparkan pada intensitas cahaya yang terkontrol, diletakkan pada kedalaman yang diatur (hormesis)

- Ketahanan karang terhadap cahaya diukur dengan imaging pulse amplitude modulated fluorometer.

- Karang yang bertahan akan ditanam di laut.

3. Laboratorium Air

Mengidentifikasi sumber pencemaran air, dengan cara :

- Sampel air diambil pada beberapa titik.

- Pengukuran parameter salinitas, suhu, transparansi perairan, arus perairan, dan $\mathrm{pH}$.

- Mengidentifikasi sumber pencemaran air dan dampaknya.

- Menyediakan air bersih dengan solar panel water desalination.

4. Restorasi Terumbu Karang

Untuk mempersiapkan karang sebelum diletakkan pada artificial coral barrier.

Program Wisata (25\%)

1. Sea Walking dan Diving

Pengunjung dapat berwisata sambil menanam karang pada habitatnya untuk membantu proses restorasi.

2. Coral Reefs Gallery

Menyediakan informasi mengenai terumbu karang, menawarkan pengalaman ruang bagaimana rasanya menjadi terumbu karang yang dirusak.

3. Restoran

Terdapat area memancing, dan recycled floating island untuk menanam sayuran. Hasil dari program ini dapat digunakan untuk memenuhi kebutuhan restoran.

Pengelola (5\%)

Area kerja pengelola dan staf.

Service (10\%)

Terdiri dari hydrogen fuell cell untuk menghasilkan air bersih dan listrik, incinerator untuk mengolah sampah. 


\section{Pemilihan Tapak}

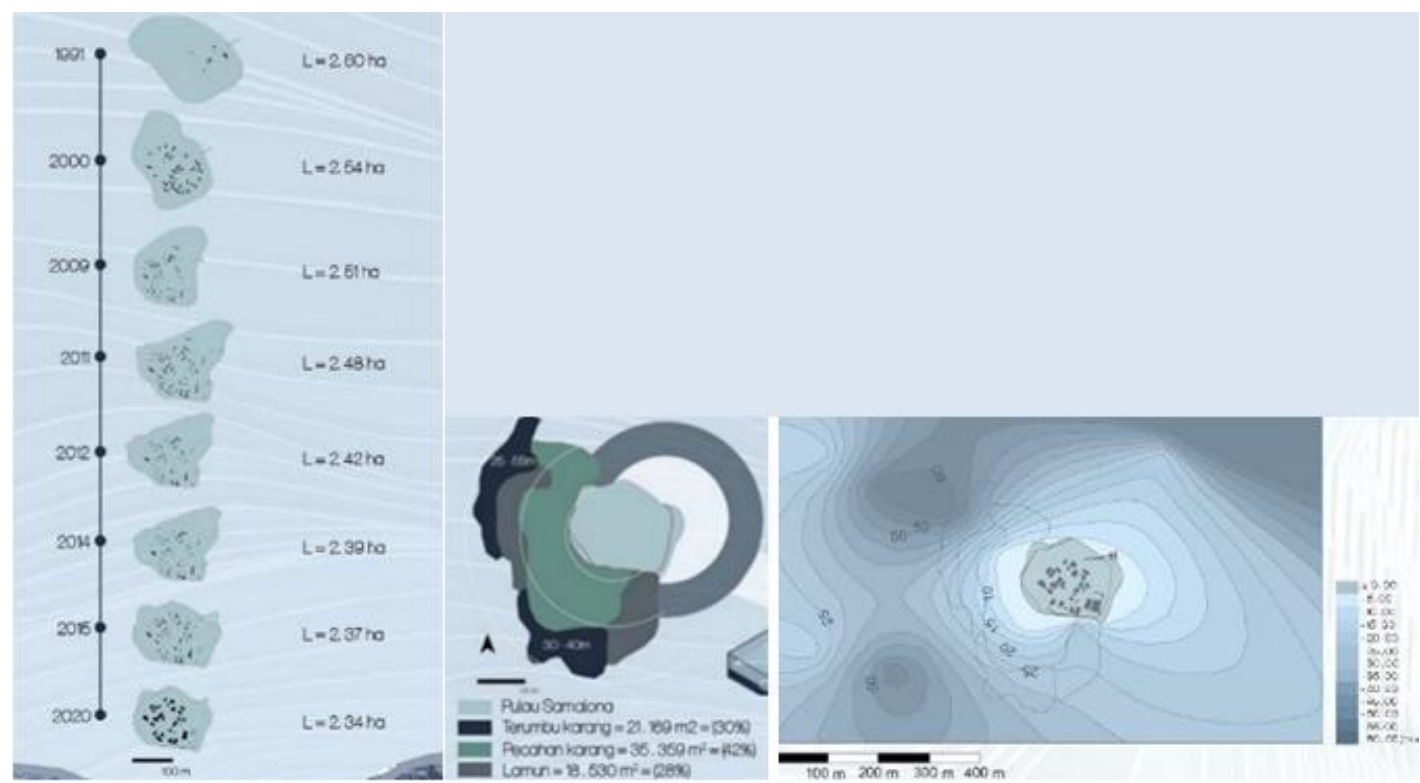

Gambar 2. Perubahan Luas Pulau Samalona dan Penyebaran Terumbu Karang di Perairan Pulau Samalona

Sumber: (Wikantari, Ishak, Imriyanti, \& Radja, 2020), (Joham, 2021), Google Earth

Menurut data dari Marine Science Diving Club (MSDC) Universitas Hasanuddin tutupan karang di sekitar Pulau Samalona dalam status buruk, yaitu 30\% sehingga perlu ditindak lanjuti. Pulau yang merupakan salah satu destinasi wisata popular bagi warga Makassar ini, memiliki bentuk yang berubah-ubah karena abrasi dan diisukan akan tenggelam. Oleh sebab itu, Pulau Samalona merupakan lokasi yang tepat untuk memulihkan terumbu karang.

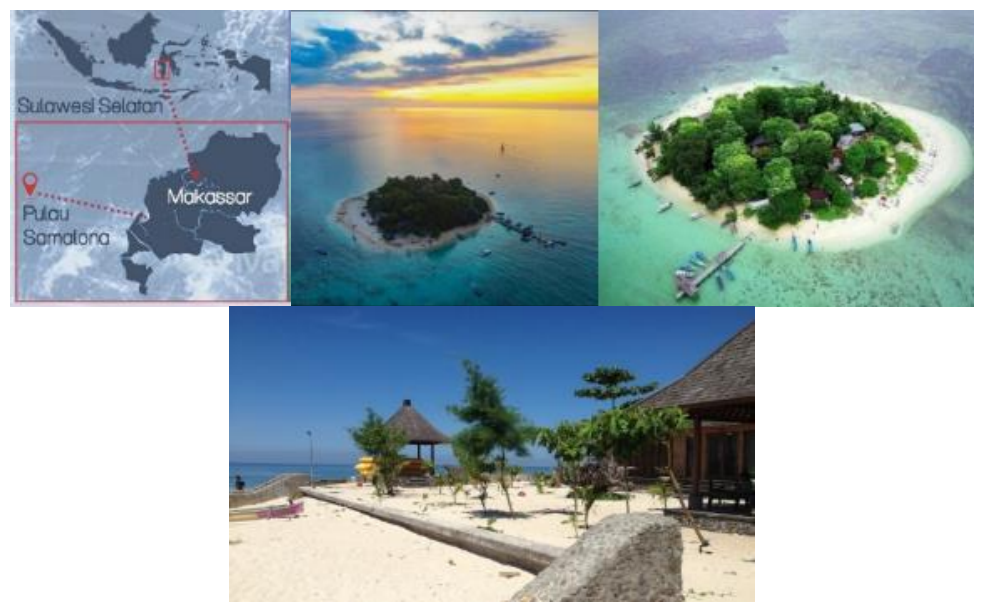

Gambar 3. Pulau Samalona.

Sumber : (Joham, 2021), (Rancupid Travel, 2017), (Rudi, 2019), (Kumparan Travel, 2019), (Indonesia Kaya, 2020)

Kondisi Perairan (Supardi \& Nugroho, 2020) :

1. Suhu

: 28,67- 29,33으.

2. $\mathrm{pH}$

: 7,25-7,36

3. Kecepatan arus

: 0,089-0,220 m/s. 
4. Kecerahan air

: 1,62-4,86 m. Baku mutu kecerahan air laut menurut Kepmen Lingkungan Hidup Nomor 51 Tahun 2004 yaitu $>5$ m.

5. Oksigen terlarut $\quad: 6,42 \mathrm{ppm}$ (tercemar ringan).

\section{Respond To Site}

1. Pencapaian

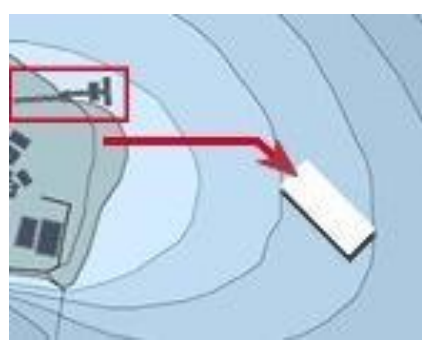

Gambar 4 : Pencapaian

Sumber : Joham , 2021

Pulau Samalona dicapai melalui dermaga yang terletak di sisi timur. Akses menuju massa diletakkan di dekat dermaga agar mudah dicapai pengunjung.

2. Topografi

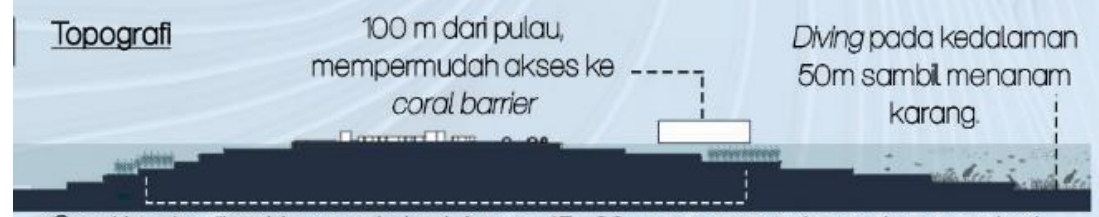

Coral barrier diletakkan pada kedalaman 15 - 20 meter agar terkena sinar matahani

Gambar 5 : Peletakan Massa Berdasarkan Topografi

Sumber : Joham , 2021

Artificial coral barrier diletakkan pada kedalaman 15-20 meter yang terletak 100 meter dari Pulau Samalona, sehingga bangunan diletakkan sekitar 100 meter dari pulau agar mempermudah akses ke artificial coral barrier.

3. Angin dan Gelombang

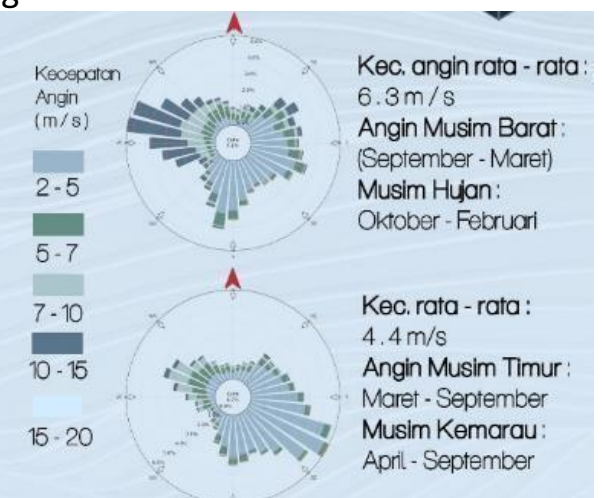

Gambar 6 : Rose Wind Diagram Pulau Samalona

Sumber : Joham , 2021

Sisi tenggara dan barat laut rentan terhadap bencana angin dan gelombang, sehingga massa diletakkan di sisi timur pulau untuk menghindari angin topan, dan massa diletakkan memanjang mengikuti arah angin. 
4. Matahari

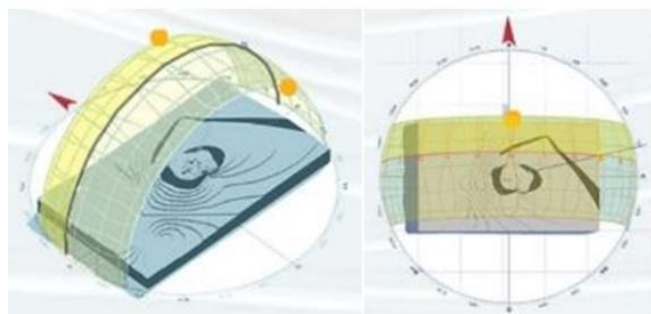

Gambar 7 : Analisis Matahari

Sumber : Joham , 2021

Matahari mendominasi sisi utara sehingga photovoltaic panel diletakkan pada sisi utara.

\section{Konsep Gubahan Massa}
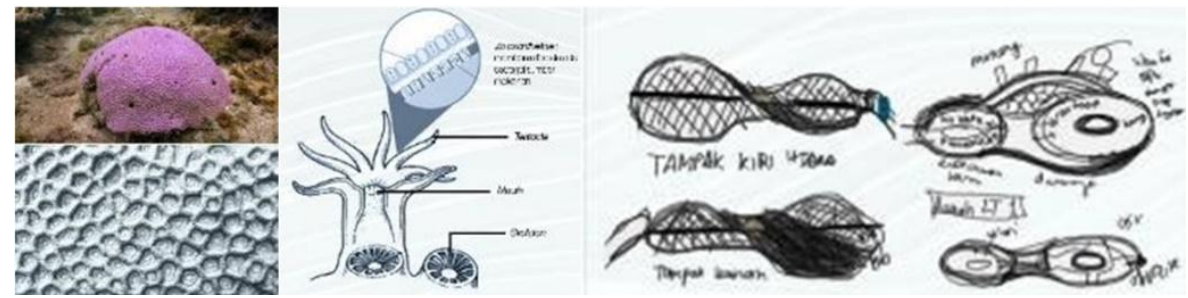

Gambar 8 : Proses Gubahan Massa

Sumber : Joham , 2021

Gubahan menganalogikan bentuk karang. Tekstur karang diaplikasikan pada tampak. Pada kulit karang terdapat algae yang disebut zooxanthellae untuk membantu proses fotosintesis sehingga karang dapat memperoleh makanannya. Hal ini diterapkan pada tampak bangunan yang menggunakan photovoltaic panel sebagai sumber energi.

\section{Proses Gubahan Massa}

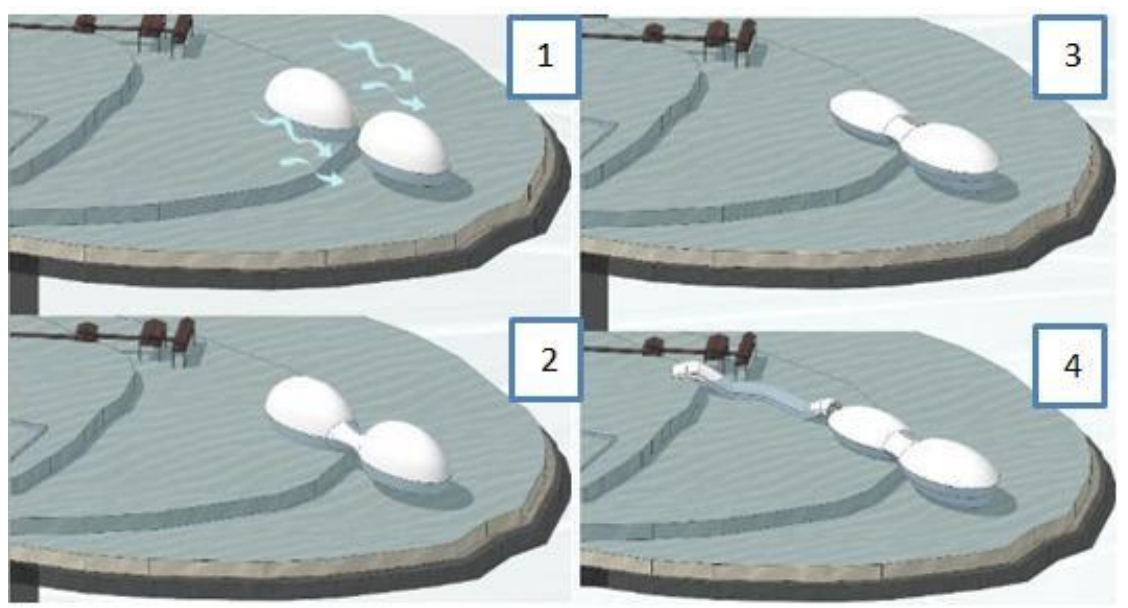

Gambar 9 : Proses Gubahan Massa

Sumber : Joham , 2021

1. Gubahan diletakkan mengikuti arah angin terkencang.

2. Melakukan programming dan zoning.

3. Bentuk bangunan mengikuti kontur tapak.

4. Dibangun sea tunnel untuk menghubungkan Pulau Samalona dan bangunan. 


\section{Zoning}

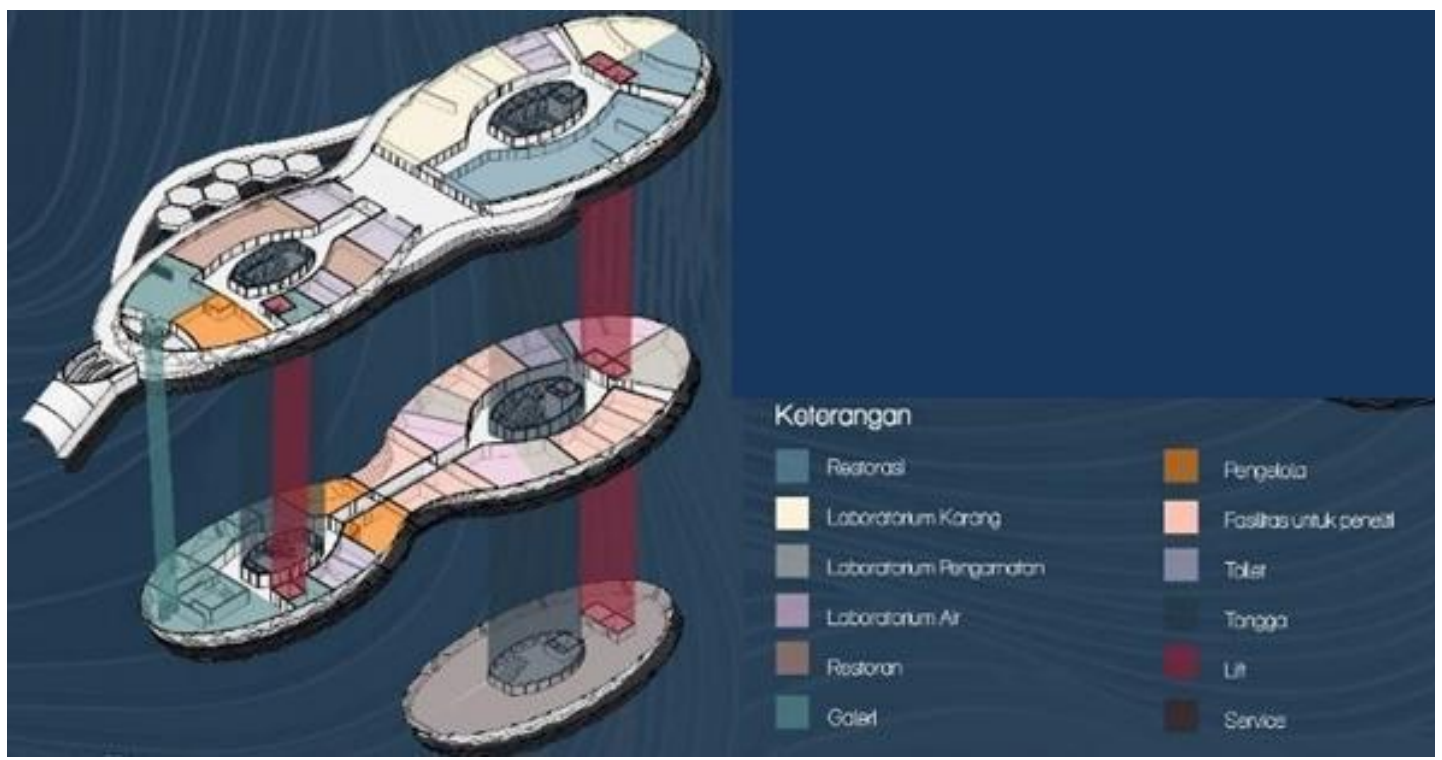

Gambar 10 : Zoning

Sumber : Joham , 2021

Zona publik terdiri dari area wisata, zona semi publik terdiri dari area restorasi, dan zona privat terdiri dari laboratorium, fasilitas peneliti, pengelola, dan area MEP.

\section{Konsep Beyond Ecology}

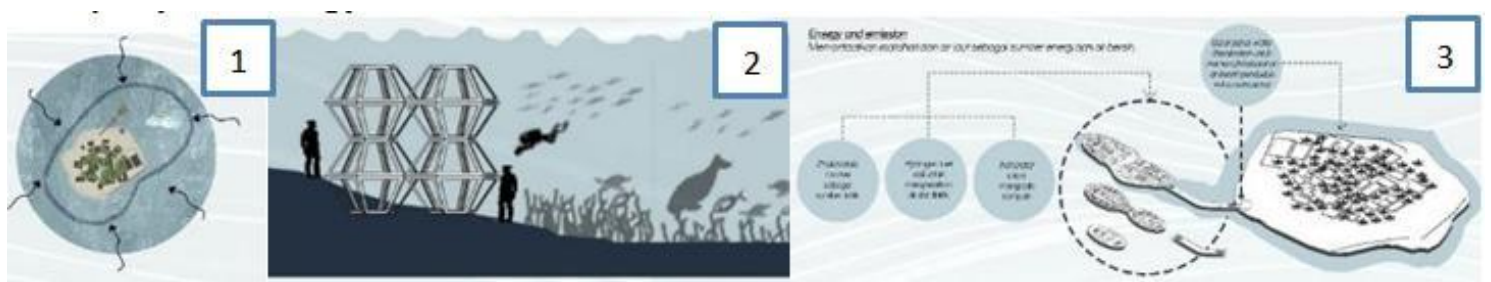

Gambar 11 : Konsep Beyond Ecology

Sumber : Joham , 2021

1. Context and adaptation

Merestorasi terumbu karang dengan menanamnya pada artificial coral barrier yang dipasang mengelilingi Pulau Samalona seperti cincin. Artificial coral barrier dapat menahan ombak untuk mencegah abrasi sehingga mencegah tenggelamnya pulau.

2. Interaction

Terjadi interaksi antara manusia, lautan, beserta makhluk-makhluknya melalui kegiatan restorasi, sea walking, dan diving.

3. Energy and emission

Memanfaatkan matahari dan air laut sebagai sumber energi dan air bersih, mengolah sampah sendiri, dan menyediakan air bersih untuk penduduk Pulau Samalona.

4. Interaction

Terdapat galeri karang basah yang menawarkan pengalaman ruang mengenai rasanya menjadi terumbu karang. 


\section{Struktur dan Material}

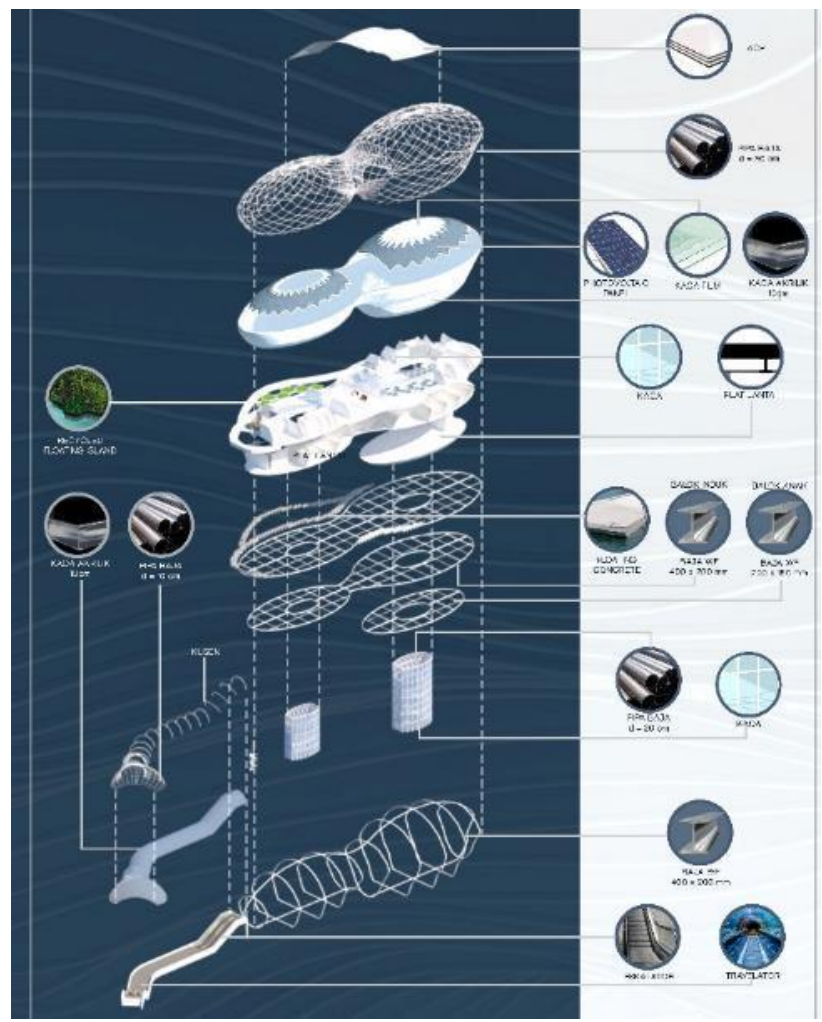

Gambar 12 : Exploded Struktur dan Material Sumber : Joham , 2021

Rangka luar menggunakan pipa baja berdiameter $30 \mathrm{~cm}$, rangka dalam menggunakan baja WF $40 \times 20 \mathrm{~cm}$ yang dihubungkan oleh balok induk dan anak dengan material yang sama. Bagian bangunan yang berada di atas air menggunakan kaca dan photovoltaic panel, sedangkan bagian yang berada di bawah air menggunakan kaca akrilik dengan ketebalan $10 \mathrm{~cm}$. Core bangunan menggunakan material pipa baja berdiameter $20 \mathrm{~cm}$ yang dihubungkan oleh baja WF $20 \times 15 \mathrm{~cm}$ pada setiap lantainya. Area dermaga dan memancing menggunakan floating concrete. Sea tunnel menggunakan kaca akrilik dengan ketebalan $10 \mathrm{~cm}$.

\section{Gambar Kerja dan Deskripsi Desain}

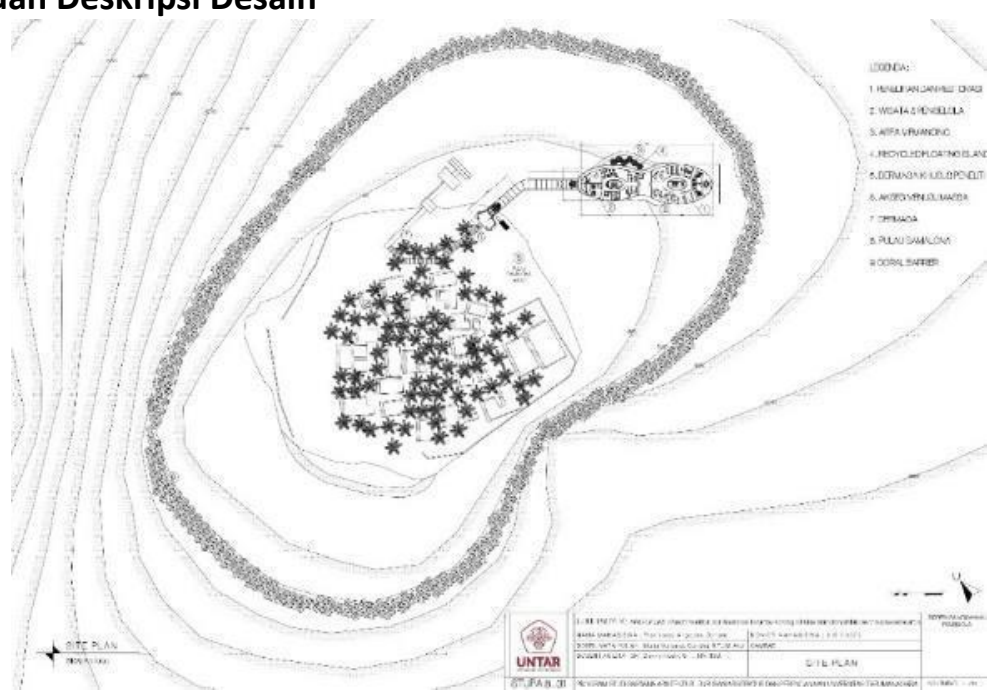

Gambar 13 : Site Plan

Sumber : Joham , 2021 
Ring of life merupakan pusat penelitian dan restorasi terumbu karang yang dikellilingi oleh artificial coral barrier sebagai media tanam karang dan melindungi Pulau Samalona dari abrasi.

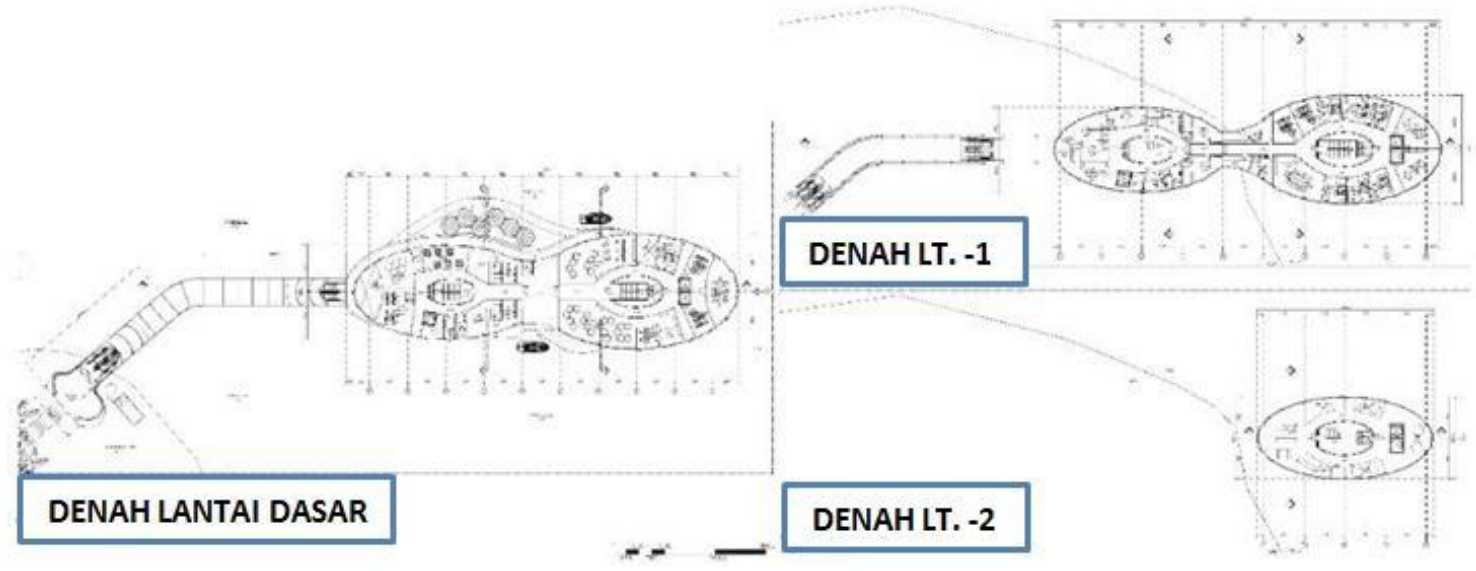

Gambar 14 : Denah Lantai Dasar, Denah Lantai -1, \& Denah Lantai -2 Sumber : Joham , 2021

Pola ruang menganalogikan skeleton karang. Lantai dasar terdiri dari galeri karang kering, wisata, penelitian, restorasi, dan pengelola. Lantai -1 terdiri dari fasilitas pendukung penelitian dan galeri karang basah. Lantai -2 merupakan lantai khusus mekanikal, elektrikal, dan plumbing.

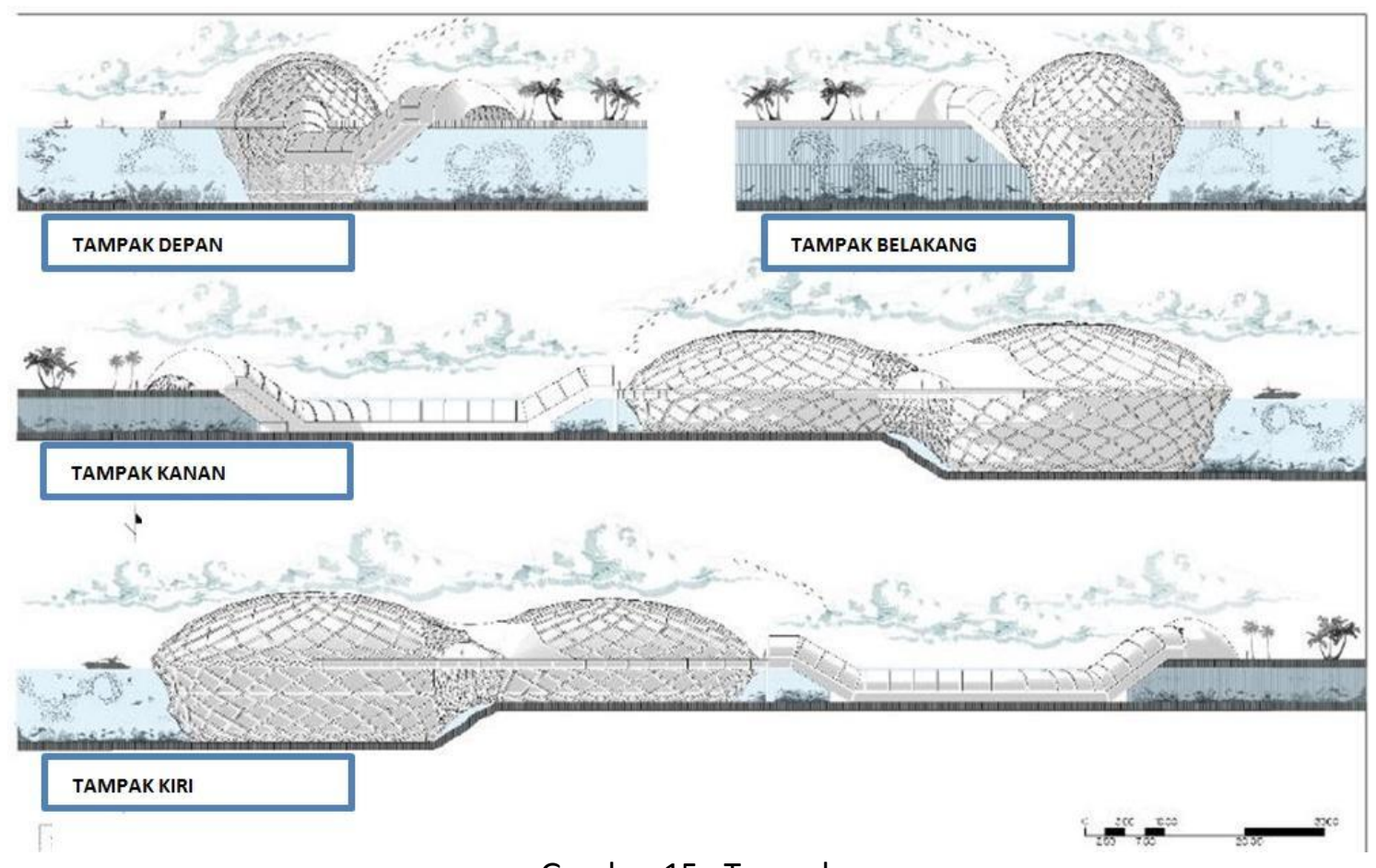

Gambar 15 : Tampak

Sumber : Joham , 2021

Tampak bangunan menganalogikan tekstur terumbu karang dan menggunakan photovoltaic panel sebagai sumber energi yang merepresentasikan zooxanthellae pada kulit karang. 

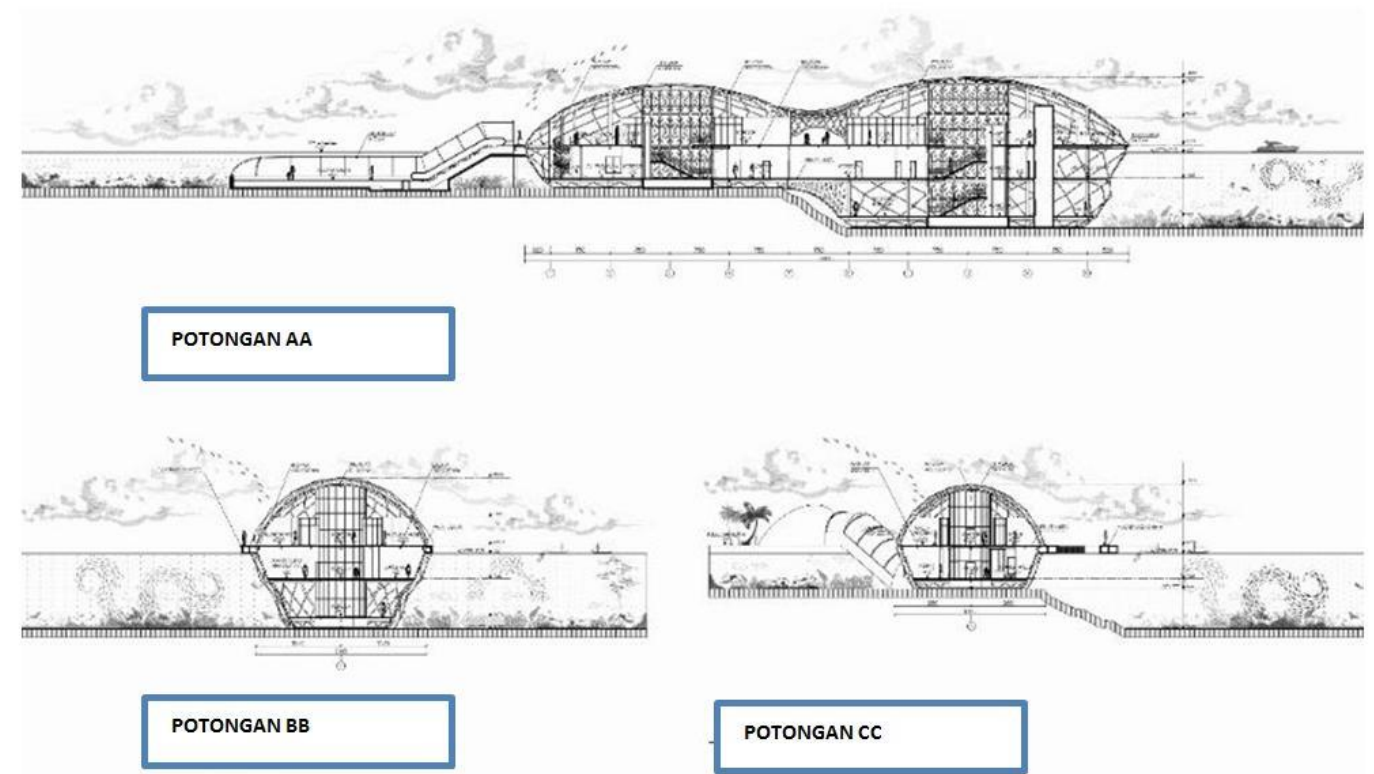

过

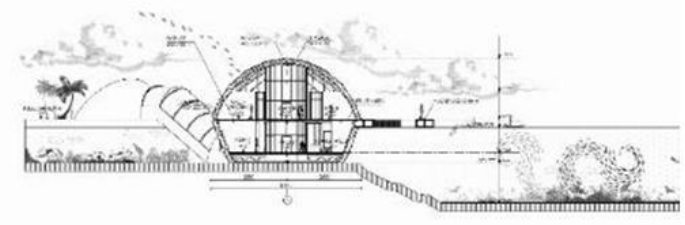

POTONGAN CC

Gambar 16 : Potongan

Sumber : Joham , 2021

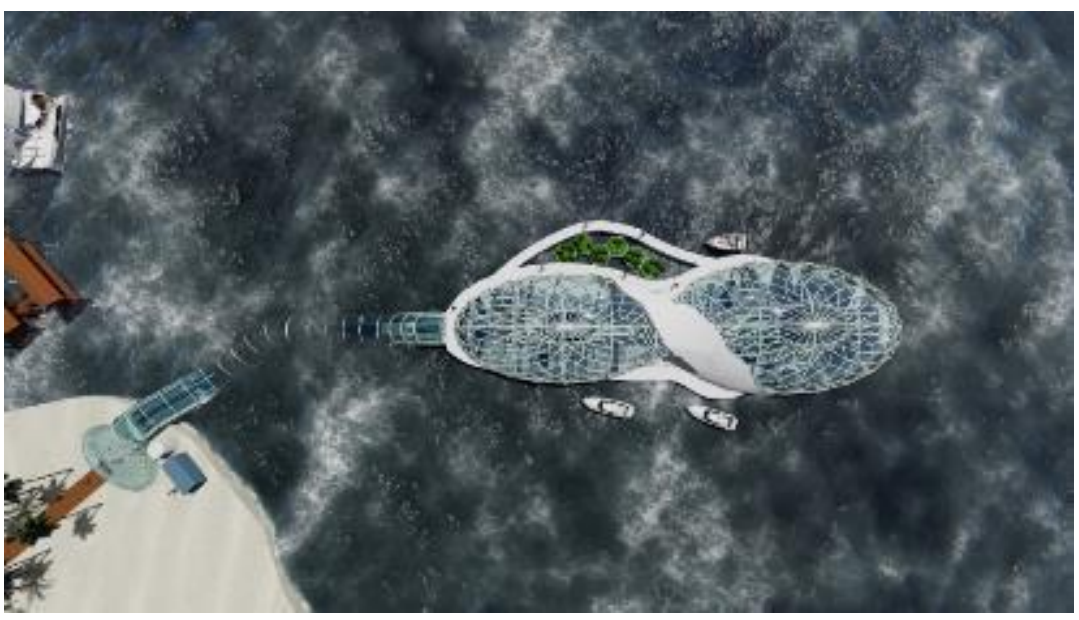

Gambar 17 : Perspektif Bird Eye View

Sumber : Joham , 2021

Bangunan dapat dicapai melalui dermaga khusus untuk peneliti, staff, dan servis. Wisatawan dapat mencapai bangunan melalui Pulau Samalona, lalu masuk ke dalam sea tunnel yang menghubungkan pulau dengan bangunan.
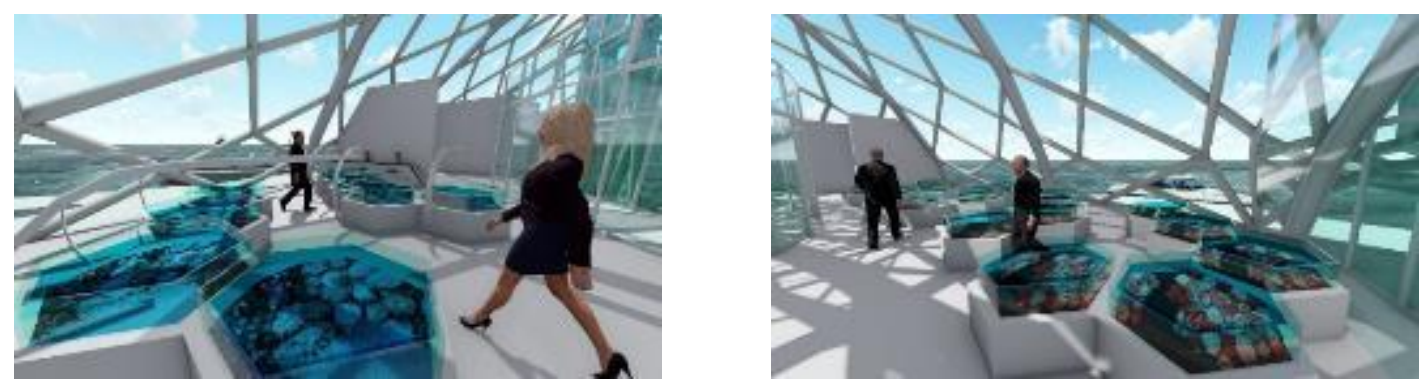

Gambar 18 : Perspektif Interior Laboratorium Karang dan Area Restorasi Sumber : Joham , 2021 
Pada laboratorium karang, akan dilakukan proses hormesis untuk menguji ketahanan karang terhadap kondisi iklim yang buruk. Selanjutnya, karang yang tahan uji akan di simpan pada tank restorasi sebelum dibawa ke laut.

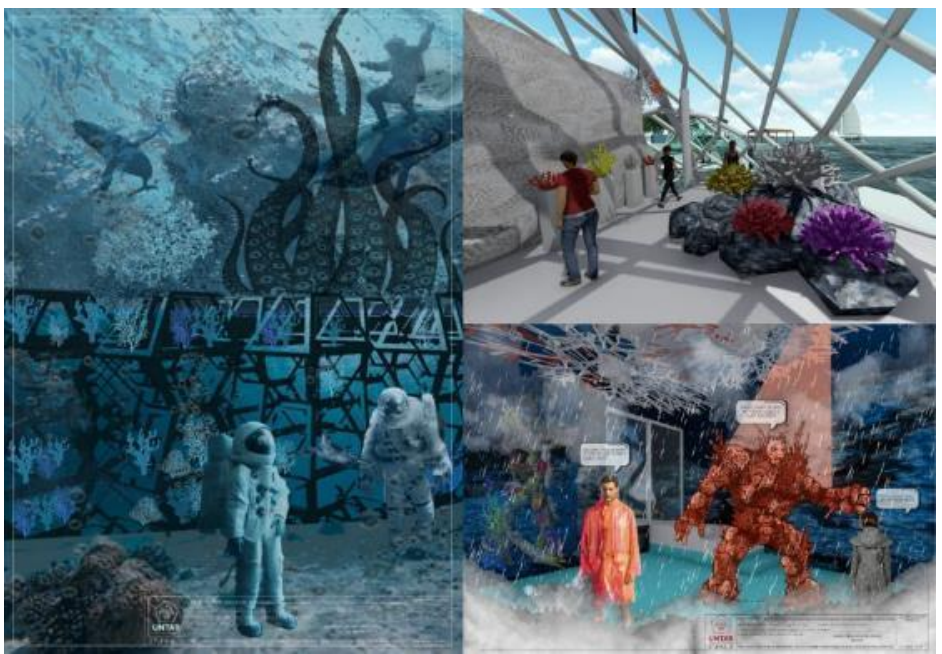

Gambar 19 : Perspektif Eksterior Artificial Coral Barrier, Interior Galeri Karang Kering dan Basah Sumber : Joham , 2021

Setelah karang siap untuk dibawa ke laut, karang akan dipasang pada artificial coral barrier oleh peneliti dan juga para wisatawan sambil melakukan aktivitas sea walking dan diving. Terdapat galeri karang kering dan basah yang dapat dikunjungi oleh pengunjung. Galeri kering menyajikan informasi-informasi mengenai terumbu karang. Galeri basah menawarkan pengalaman ruang bagaimana rasanya menjadi terumbu karang dengan menggunakan hologram yang menampilkan karang yang mengungkapkan perasaannya kepada manusia. Menggunakan dry ice yang mewakili penangkapan ikan dengan bahan peledak dan zat berbahaya yang dapat ikut merusak terumbu karang.

\section{Sistem Mekanikal Elektrikal Plumbing}

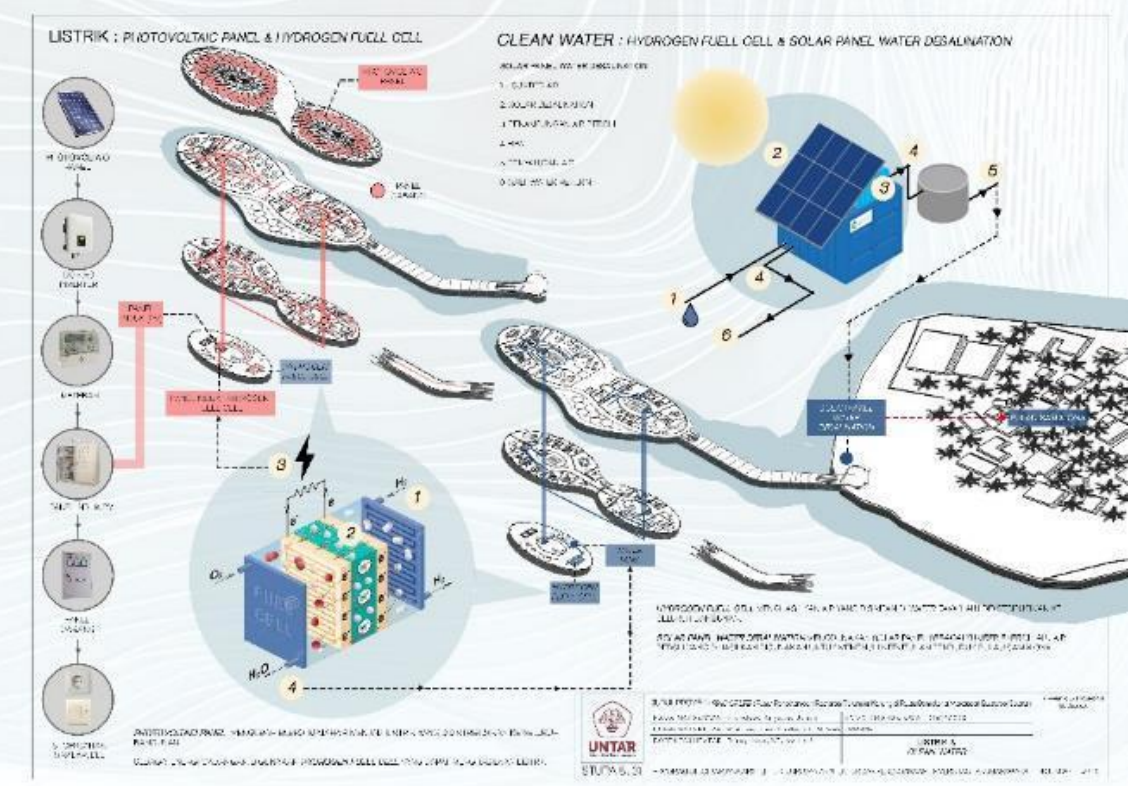

Gambar 20 : Sistem Kelistrikan dan Clean Water Sumber : Joham , 2021 
Listrik diperoleh dari photovoltaic panel dan hydrogen fuell cell. Hydrogen fuell cell juga dapat menghasilkan air bersih yang salurkan ke seluruh bangunan. Untuk memenuhi kebutuhan air bersih penduduk Pulau Samalona, digunakan solar panel water desalination.

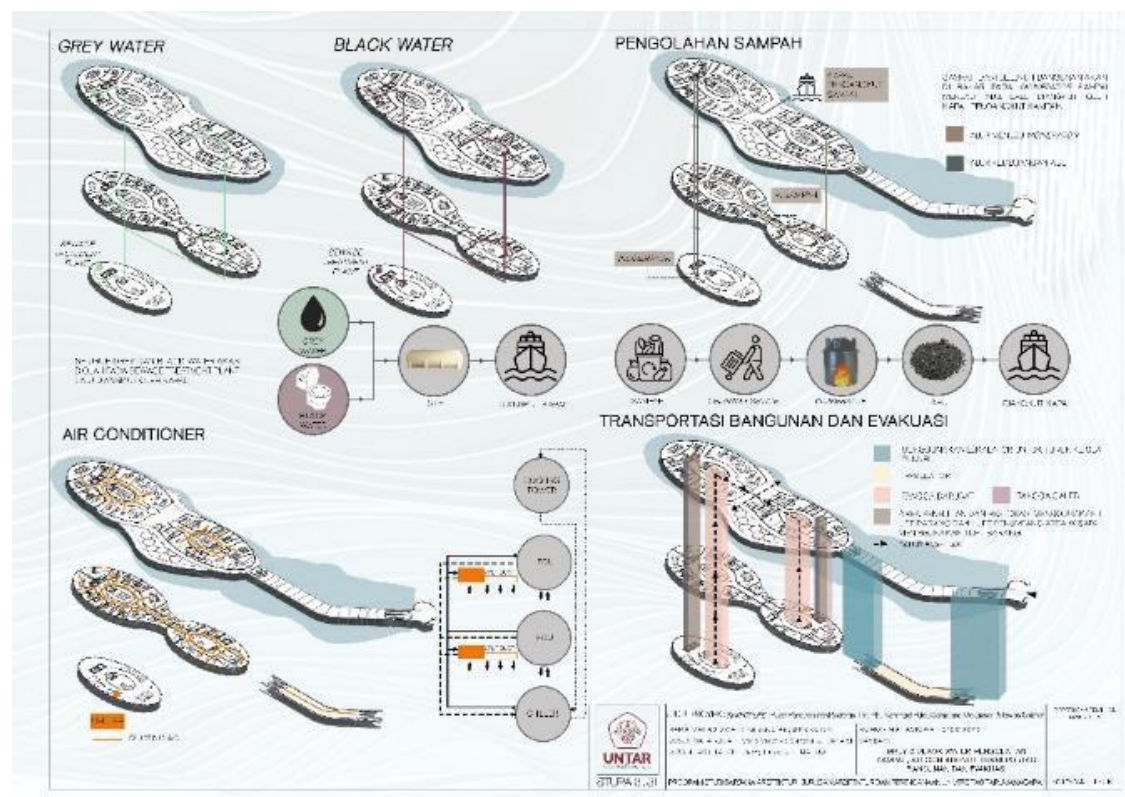

Gambar 21 : Sistem Grey \& Black Water, Pengolahan Sampah, Air Conditioner, dan Transportasi Bangunan

Sumber : Joham , 2021

Grey dan black water dialirkan ke sewage treatment plant (STP) untuk diolah, lalu diangkut oleh kapal. Sampah dari seluruh bangunan diolah pada incinerator sampai menjadi abu, lalu diangkut oleh kapal. Menggunakan system AC sentral. Transportasi pada bangunan menggunakan tangga dan lift, sedangkan pada sea tunnel menggunakan escalator dan travellator.

\section{KESIMPULAN DAN SARAN}

\section{Kesimpulan}

Aspek beyond ecology dari proyek ini adalah context and adaptation dimana terumbu karang direstorasi pada artificial coral barrier yang sekaligus dapat melindungi Pulau Samalona dari abrasi, interaction yaitu terjadi interaksi antara manusia dan laut, energy and emission yaitu memanfaatkan sinar matahari dan air laut sebagai sumber energi dan air bersih serta menyediakan air bersih untuk Pulau Samalona, dan menawarkan pengalaman ruang bagi manusia untuk merasakan rasanya menjadi terumbu karang untuk meningkatkan kepedulian. Diharapkan Ring of Life dapat mengembalikan tutupan karang di perairan Pulau Samalona menjadi status baik sehingga keindahan dan manfaat terumbu karang dapat tetap dinikmati oleh generasi selanjutnya.

\section{Saran}

Penulis berharap studi terumbu karang yang dapat bertahan terhadap kondisi iklim ekstrim terus mengalami perkembangan. Sebagai ciptaan Tuhan yang paling mulia, manusia harus lebih peduli dengan alam karena jika kita melindungi alam, alam akan berbalik melindungi kita. 


\section{REFERENSI}

Anantara. (2019, November 14). Sulawesi Bisnis. Diambil kembali dari Bisnis.com: https://sulawesi.bisnis.com/read/20191114/539/1170602/kerusakan-terumbu-karangspermonde-mendesak-diatasi

Chandra, W. (2016, Januari 15). Diambil kembali dari Mongabay.com: https://www.mongabay.co.id/2016/01/15/terumbu-karang-pesisir-makassar-rusakparah-dampak-reklamasi/

Collins. (t.thn.). Diambil kembali dari https://www.collinsdictionary.com/dictionary/english/research-centre

Edwards, A. J., \& Gomez, E. D. (2007). Konsep \& Panduan Restorasi Terumbu : Membuat pilihan bijak di antara ketidakpastian. Jakarta: Yayasan Terumbu Karang Indonesia.

Hadi, T. A., Bayu, G., Prayudha, B., Hafizt, M., Budiyanto, A., \& Suharsono. (2018). Status Terumbu Karang Indonesia 2018. Jakarta: Pusat Penelitigan Oseanografi - Lembaga IImu Pengetahuan Indonesia.

Kumparan. (2019, December 1). Kumparan Travel. Diambil kembali dari Kumparan : https://kumparan.com/kumparantravel/greenpeace-kondisi-terumbu-karang-dikepulauan-spermonde-memburuk-1sMPpcc2S8P/full

Lubis, S. B., Suraji, Mudatstir, Miastro, Y., Puspitasari, R., Monintja, M., . . Sitorus, E. N. (2016). Rencana Aksi Nasional (RAN) Konservasi Karang. Jakarta: Kementerian Kelautan dan Perikanan, Direktorat Jenderal Pengelolaan Ruang Laut, Direktorat Konservasi dan Keanekaragaman Hayati Laut.

Rudi. (2019, October 4). Diambil kembali dari Native Indonesia: https://www.nativeindonesia.com/pulau-samalona/

Sutanto, A. (2020). Dalam Peta Metode Desain (hal. 227). Jakarta.

Sutanto, A. (2021). Dromos Oikos Notes on The FIfth Ecology [Presentasi Power Point]. Jakarta.

Supardi, W., \& Nugroho, P. A. (2020). Bioakumulasi Timbal (Pb) Pada Makroalga Padina australis Hauck. Bioma, 7.

Wikantari, R., Ishak, R. A., Imriyanti, \& Radja, A. M. (2020). MODEL TATA RUANG DAN BANGUNAN TANGGAP BENCANA. unhas, 8.

Zurba, N. (2019). Pengenalan Terumbu Karang Sebagai Pondasi Utama Laut Kita. Lhokseumawe: Unimal Press.

(2017). Diambil kembali dari Rancupid Travel: http://rancupidtravel.com/tours/explore-pulausamalona-makassar-3d2n/

(2020, January 15). Diambil kembali dari Arsy Tours: https://www.arsytours.com/pulausamalona-destinasi-bahari-yang-wajib-disambangi-di-makassar/

(2020). Diambil kembali dari Indonesia Kaya: https://www.indonesiakaya.com/ielajahindonesia/detail/menikmati-eksotisnya-pulau-samalona-di-bumi-makassar 